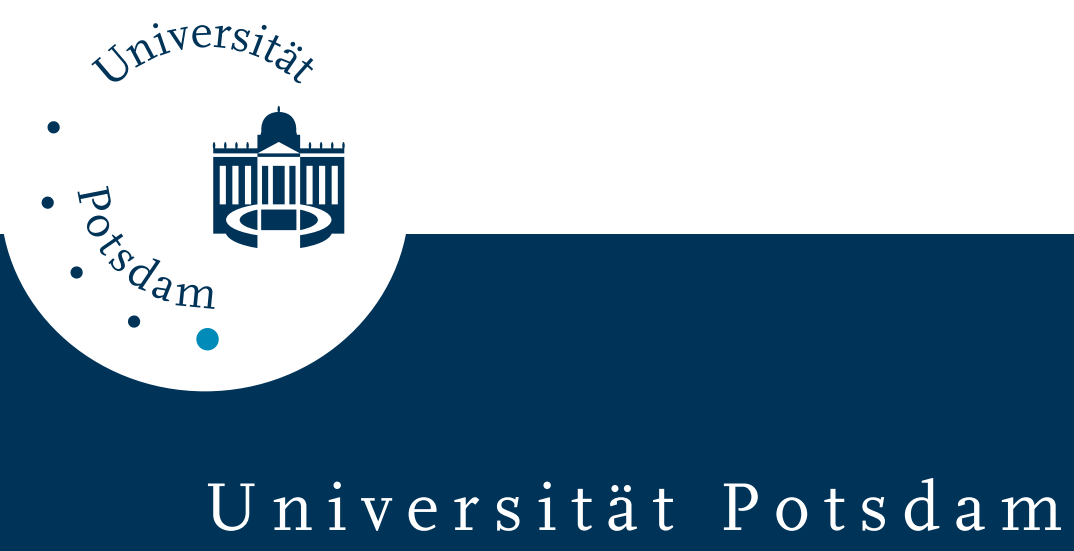

Thilo Heinken, Marcus Schmidt, Goddert von Oheimb, Wolf-Ulrich Kriebitzsch, Hermann Ellenberg

\title{
Soil seed banks near rubbing trees indicate dispersal of plant species into forests by wild boar
}

first published in:

Basic and applied ecology. - 7 (2006), 1, S. 31 - 44,

DOI 10.1016/j.baae.2005.04.006

Postprint published at the Institutional Repository of the Potsdam University:

In: Postprints der Universität Potsdam

Mathematisch-Naturwissenschaftliche Reihe ; 150

http://opus.kobv.de/ubp/volltexte/2010/4647/

http://nbn-resolving.de/urn:nbn:de:kobv:517-opus-46476

Postprints der Universität Potsdam

Mathematisch-Naturwissenschaftliche Reihe ; 150 



\title{
Soil seed banks near rubbing trees indicate dispersal of plant species into forests by wild boar
}

\author{
Thilo Heinken, Marcus Schmidt, Goddert von Oheimb, Wolf-Ulrich Kriebitzsch and Hermann \\ Ellenberg
}

Address for correspondence:

Thilo Heinken, Institut für Biochemie und Biologie, Biozönoseforschung/Spezielle Botanik, Universität Potsdam, D-14471 Potsdam, Germany

Phone number: +49 331 977-4854

Fax number: +49 331 977-4865

E-mail: heinken@rz.uni-potsdam.de

\begin{abstract}
Current knowledge about processes that generate long-distance dispersal of plants is still limited despite its importance for persistence of populations and colonization of new potential habitats. Today wild large mammals are presumed to be important vectors for long-distance transport of diaspores within and between European temperate forest patches, and in particular wild boars recently came into focus. Here we use a specific habit of wild boar, i.e. wallowing in mud and subsequent rubbing against trees, to evaluate epizoic dispersal of vascular plant diaspores. We present soil seed bank data from 27 rubbing trees versus 27 control trees from seven forest areas in Germany. The mean number of viable seeds and the plant species number were higher in soil samples near rubbing trees compared with control trees. Ten of the 20 most frequent species were more frequent, and many species exclusively appeared in the soil samples near rubbing trees. The large number of plant species and seeds - approximated $>1000$ per tree - in the soils near rubbing trees is difficult to explain unless the majority were dispersed by wild boar. Hooked and bristly diaspores, i.e. those adapted to epizoochory, were more frequent, above that many species with unspecialised diaspores occurred exclusively near rubbing trees. Different to plant species closely tied to forest species which occur both in forest and open vegetation, and non-forest species were more frequent near rubbing trees compared with controls. These findings are consistent with previous studies on diaspore loads in the coats and hooves of shot wild boars. However, our method allows to identify the transport of diaspores from the open landscape into forest stands where they might especially emerge after disturbance, and a clustered distribution of epizoochorically dispersed seeds. Moreover, accumulation of seeds of wetness indicators near rubbing trees demonstrates directed dispersal of plant species inhabiting wet places between remote wallows.
\end{abstract}

\section{Zusammenfassung}

Das aktuelle Wissen über Prozesse, die zur Fernausbreitung von Pflanzen führen, ist trotz ihrer Bedeutung für das Überleben von Populationen und die Besiedlung neuer potenzieller Habitate noch immer sehr begrenzt. Wildlebende Großsäuger sind heutzutage vermutlich wichtige Vektoren für den Ferntransport von Diasporen innerhalb und zwischen den einzelnen Waldflächen in Mitteleuropa, und speziell das Wildschwein (Sus scrofa L.) spielt dabei offenbar eine herausragende Rolle. Wir nutzen hier ein spezifisches Verhalten des Wildschweins - Suhlen im Schlamm und nachfolgendes Scheuern an sogenannten Malbäumen um die epizoochore Ausbreitung von Gefäßpflanzen-Diasporen einzuschätzen. Dargestellt werden die Ergebnisse von Samenbank-Untersuchungen von 27 Malbäumen im Vergleich zu 27 Kontrollbäumen aus sieben Waldgebieten in Deutschland. Sowohl die mittlere Zahl lebensfähiger Samen als auch die Artenzahl waren höher in Bodenproben neben Malbäumen. Zehn der 20 in der Samenbank verbreitetsten Pflanzenarten hatten hier ihren Schwerpunkt, und viele Arten kamen ausschließlich in den neben Malbäumen gewonnenen Proben vor. Die große Zahl von Pflanzenarten und Samen - zumindest > 1000 pro Baum - im Boden an Malbäumen lässt sich nur durch die Aktivität der Wildschweine erklären. Mit Haken oder Borsten ausgestattete, d.h. an Epizoochorie angepasste Diasporen waren häufiger, aber auch viele Arten mit unspezialisierten Diasporen kamen ausschließlich in der Samenbank bei Malbäumen vor. Anders als weitgehend an Wald gebundene Pflanzenarten waren 
solche, die sowohl im Wald und im Offenland vorkommen, sowie nicht im Wald vorkommende Arten häufiger neben Malbäumen als neben Kontrollbäumen. Diese Befunde stimmen mit denen früherer Untersuchungen von Diasporenladungen im Fell und in den Hufen geschossener Wildschweine überein. Unsere Methode erlaubt darüber hinaus aber die Identifizierung des Diasporentransports aus dem Offenland in die Waldbestände, wo sie insbesondere nach Störungen keimen dürften, sowie einer ungleichmäßigen Verteilung epizoochor ausgebreiteter Diasporen. Außerdem zeigt die Akkumulation von Samen von Nässezeigern neben den Malbäumen eine gezielte Ausbreitung nasse Standorte bewohnender Pflanzenarten zwischen entfernt gelegenen Suhlen.

\section{Key words:}

diaspore morphology - directed dispersal - epizoochory -long-distance dispersal - Sus scrofa - temperate forest - wallow

\section{Introduction}

A large proportion of European temperate forest ecosystems are fragmented, small forest areas (Wulf 2003). At present, environmental changes due to atmospheric depositions, global warming and changes in silvicultural practices (e.g. conversion of single-species, even-aged coniferous forests into mixed species, closer to nature forests) alter local habitat conditions and thereby cause changes in species composition and modulate species loss (Diekmann, Brunet, Rühling \& Falkengren-Grerup 1999, Zerbe 2002). In addition, forest cover is growing due to afforestation and secondary succession on formerly agricultural land (Klein 1997, Levy \& Milne 2004). Strong positive relationships between forest age and diversity of typical understory species have been reported frequently (Peterken \& Game 1984, Wulf 2004), indicating slow colonization by many species. Dispersal limitation has been identified as one of the main causes for the low colonization capacity observed for many forest plants (Brunet \& von Oheimb 1998, Heinken 2004).

Long-distance dispersal is essential both for the long-term viability and persistence of plant populations by maintaining migration between isolated habitats (Ouborg, Piquot \& van Groenendael 1999), and for the colonization of new potential habitats. Despite the importance of long-distance dispersal events the current knowledge about the processes that generate these events is limited (Cain, Milligan \& Strand 2000, Higgins, Nathan \& Cain 2003). Today the main vectors for long-distance transport of diaspores within and between European temperate forest patches are wild birds and large mammals, and modern forestry itself by means of machines or cars (Bonn \& Poschlod 1998, Gill \& Beardall 2001). While the effects of fruit consumption by vertebrate frugivores (mainly birds) on seed dispersal has received considerable attention (Bonn \& Poschlod 1998, Kollmann 2000), only recently wild large mammals came into focus as effective epi- and endozoochorous dispersers of a wide range of plant species (Mrotzek, Halder \& Schmidt 1999, Welander \& Weibull 2000, Heinken, Hanspach, Raudnitschka \& Schaumann 2002, Heinken \& Raudnitschka 2002, Schmidt, Sommer, Kriebitzsch, Ellenberg \& von Oheimb 2004, von Oheimb, Schmidt, Kriebitzsch \& Ellenberg in press). Epizoochorous dispersal of diaspores on fur and feet of large mammals is presumed to be among the most important long-distance dispersal mechanisms because of a long retention time of several hours up to several days and large home ranges during a single day. In the actual central European landscape, in particular wild boar (Sus scrofa L.) has the potential of being a main vector for epizoochorous seed dispersal due to its fur characteristics, behaviour, large local population size, and general abundance. In the coats and hooves of shot wild boar a wide range of plant species have been found with a maximum of 1,554 diaspores and 51 plant species per animal (Mrotzek et al. 1999, Heinken \& Raudnitschka 2002, Schmidt et al. 2004).

However, using shot animals allows only for a one-time estimate of the diaspore loads. In contrast to domestic animals, where epizoochory can be studied combining repeated surveys over time by adhesivity experiments of the same live animal (Fischer, Poschlod \& Beinlich 1996, Kiviniemi 1996, Graae 2002), the methods to study epizoochory by wild large mammals are very limited. Couvreur, Vandenberghe, Verheyen \& Hermy (2004) used standardized laboratory experiments to quantify seed adhesivity on prepared fur samples of three wild and four domestic mammalian species, including wild boar fur. These experiments al- 
lowed for a controlled assessment of seed adhesion merely regarding fur and seed traits, while controlling other environmental and behavioural factors such as plant traits, vegetation characteristics, weather, animal movement and wallowing. However, these factors may be of particular importance for actual diaspore attachment, transport and detachment.

In this study, we focus on a particular habit of wild boar and estimate the abundance and composition of vascular plant diaspores externally dispersed. Wild boar likes a good wallow in the mud, to achieve heat reduction and relief from insects and parasites. Wild boar wallows are found in moist sites, i.e. places that may contain stagnant water nearly the whole year, but often are just muddy, such as edges of flooded areas, ditches or muddy depressions in trails (Dardaillon 1986, Welander 2000). After wallowing, the animals move to a tree and rub against it, with the result that the tree trunk becomes muddy and thus conspicuous. Rubbing trees in forests are, in general, very close to wallows (Bavoux 1981, Welander 2000). We collected soil samples near rubbing trees and control samples next to adjacent trees in different German forest areas. Soil samples were then analysed for germination of vascular plants.

Based on first preliminary results from single forest areas in Germany (Mrotzek et al. 1999) and Sweden (Welander \& Weibull 2000) we hypothesize that most diaspores that occur in control samples should also be found in soil samples collected near rubbing trees, whereas the latter should include additional diaspores externally dispersed by wild boar and deposited near rubbing trees. We therefore expect soil seed bank near rubbing trees to be richer in diaspore and species number of vascular plants than near control trees. On shot wild boars diaspores with adhesive appendages or small seeded species and herbaceous species which grow both in forests as well as in open vegetation or exclusively occur in open vegetation predominate (Heinken \& Raudnitschka 2002, Schmidt et al. 2004). Therefore we predict that plant species with specific diaspore morphology or habitat preference accumulate near rubbing trees because they are favoured by wild boar dispersal. We also assume that deposition of seeds near rubbing trees indicates local effects on soil seed bank and vegetation composition in central European woodlands.

\section{Materials and Methods Study areas}

We selected seven forest areas, with different vegetation and from different central European landscapes, for the field study (Table 1). Five (AT, BE, HO, ST and SZ) are located in the lowlands of NW Germany, in the southeast of Schleswig-Holstein and the west of Mecklenburg. Here, sandy (AT) or loamy deposits of the Weichsel glacial are characteristic. Two study sites (KW and RW) are located in the low mountain ranges of central Germany, in the north of Hesse. The geological substrate is Triassic sandstone with loess cover, and soils are loamy throughout. Forest vegetation is characterized by both different types of deciduous forest and coniferous plantations. With the exception of RW, the investigated forest patches are small or medium-sized and surrounded predominantly by agricultural land. Instead of that a wide forest aisle with grassland was near the investigated rubbing trees in RW.

\section{Sampling and seed bank study}

We collected soil samples in the study areas between 31 October and 8 December 2002 , after seed set had ended for most plant species. In a perimeter of $20 \mathrm{~m}$ around large wallows we located rubbing trees which are identifiable by bark damage and adhesive soil with wild boar's bristles. Near the basis of the trees fresh litter was removed. We took 5 samples near each of 27 rubbing trees and 27 control trees, to a depth of $5 \mathrm{~cm}$ with a core sampler of $5 \mathrm{~cm}$ diameter, i.e. containing $100 \mathrm{ml}$ and pooled them, resulting in a total sample of $500 \mathrm{ml}$ soil per tree. Soil samples were taken as close as possible to the trunk of the tree side where wild boar had performed most rubbing, and immediately placed in plastic bags. We took control samples near the trunks of the same tree species as the rubbing tree, typically less than $10 \mathrm{~m}$ from the sampled rubbing tree and showing no signs of wild boar activities. 
Table 1. The study areas and their site characteristics.

\begin{tabular}{|c|c|c|c|c|c|c|}
\hline Code & Name & Location & $\begin{array}{l}\text { Forest } \\
\text { area } \\
\text { [ha] }\end{array}$ & $\begin{array}{l}\text { Dominating forest } \\
\text { vegetation }\end{array}$ & $\begin{array}{c}\text { Rubbing tree spe- } \\
\text { cies }\end{array}$ & $\begin{array}{c}\text { No. of } \\
\text { samples } \\
\text { (wallows) }\end{array}$ \\
\hline AT & Albsfelder Tannen & $\begin{array}{l}\text { lat } 53^{\circ} 40^{\prime} \\
\text { long } 10.42^{\prime}\end{array}$ & 400 & $\begin{array}{c}\text { Acid-soil beech for- } \\
\text { est } \\
\text { coniferous forest }\end{array}$ & $\begin{array}{c}\text { Picea abies } \\
\text { Pseudotsuga } \\
\text { menziesii }\end{array}$ & $2(2)$ \\
\hline $\mathrm{BE}$ & Berkenstrücken & $\begin{array}{l}\text { lat } 53^{\circ} 41^{\prime} \\
\text { long } 10^{\circ} 41^{\prime}\end{array}$ & 150 & $\begin{array}{l}\text { Mesic beech forest } \\
\text { coniferous forest } \\
\text { alder swamp forest }\end{array}$ & Picea abies & $5(1)$ \\
\hline $\mathrm{HO}$ & Hollenbek & $\begin{array}{l}\text { lat } 53^{\circ} 43^{\prime} \\
\text { long } 10^{\circ} 40^{\prime}\end{array}$ & 20 & $\begin{array}{l}\text { Mesic beech forest } \\
\text { coniferous forest }\end{array}$ & Picea abies & $2(1)$ \\
\hline ST & Steinhorst & $\begin{array}{l}\text { lat } 53^{\circ} 44^{\prime} \\
\text { long } 10^{\circ} 29^{\prime}\end{array}$ & 500 & $\begin{array}{l}\text { Alder-ash forest } \\
\text { Mesic beech forest }\end{array}$ & Picea abies & $3(1)$ \\
\hline$S Z$ & $\begin{array}{l}\text { Schattiner Zu- } \\
\text { schlag }\end{array}$ & $\begin{array}{l}\text { lat } 53^{\circ} 49^{\prime} \\
\text { long } 10^{\circ} 46^{\prime}\end{array}$ & 150 & $\begin{array}{l}\text { Mesic beech forest } \\
\text { coniferous forest }\end{array}$ & $\begin{array}{c}\text { Picea abies } \\
\text { Fraxinus excelsior } \\
\text { Abies grandis }\end{array}$ & $10(2)$ \\
\hline KW & $\begin{array}{l}\text { Near Kaufunger } \\
\text { Wald (Dohren- } \\
\text { bach) }\end{array}$ & $\begin{array}{l}\text { lat } 51^{\circ} 18^{\prime} \\
\text { long } 09^{\circ} 50^{\prime}\end{array}$ & 80 & Mesic beech forest & $\begin{array}{l}\text { Carpinus betulus } \\
\text { Fagus sylvatica }\end{array}$ & $3(1)$ \\
\hline RW & $\begin{array}{l}\text { Reinhardswald } \\
\text { (Elsterbachtal) }\end{array}$ & $\begin{array}{l}\text { lat } 51^{\circ} 24^{\prime} \\
\text { long } 09^{\circ} 36^{\prime}\end{array}$ & 20000 & $\begin{array}{c}\text { Acid-soil beech for- } \\
\text { est } \\
\text { coniferous forest }\end{array}$ & Picea abies & $2(2)$ \\
\hline
\end{tabular}

We determined the number of viable seeds in the soil samples by greenhouse germination (seedling emergence method) under conditions supposed to promote the germination of most forest understorey plant species. The samples were spread in plastic trays $(60 \times 40 \times 7$ $\mathrm{cm}$ ). The greenhouse conditions were kept at $20^{\circ} \mathrm{C}$ during $12 \mathrm{~h}$ of artificial light (Phillips SonT Agro $400 \mathrm{~W}$ lamp) and at $16{ }^{\circ} \mathrm{C}$ during $12 \mathrm{~h}$ of darkness during winter months, and at day temperatures of $25^{\circ} \mathrm{C}$ and night temperatures of $16^{\circ} \mathrm{C}$ under natural light during summer months. Trays were covered with plastic lids to prevent additional diaspore supply. We identified and counted emerging seedlings, and then removed them as soon as possible to promote the emergence of other seedlings. Unidentifiable seedlings were transplanted and grown in individual pots until identification was possible. To achieve a cold stratification we exposed the trays to frost during the winter period. In April 2003 all remaining unidentified seedlings were replanted for later identification. The soil samples were thereafter stirred in order to activate still dormant seeds. We terminated the experiment on 27 September 2003, and grouped seedlings still not identified to their respective genera. The nomenclature of the plant species follows Wisskirchen \& Haeupler (1998).

\section{Classification of diaspores}

To determine whether morphological diaspore characters thought to facilitate specific dispersal modes were associated with a high seed abundance in the soil seed bank near rubbing trees, we classified all diaspores (seeds and fruits) according to their dispersalrelevant properties: hooked - with hooked or barbed appendages (adapted to epizoochory); bristly - with straight appendages (adapted to epizoochory); winged - flat with wing-like structures enabling flight; hair - with long hairs enabling flight; pulp - with fleshy fruit pulp (adapted to endozoochory); unspecific - without features furthering dispersal, including diaspores with elaiosome adapted to ant dispersal.

We classified regional habitat preference of all taxa which germinated in the soil samples according to the "list of vascular forest plant species of Germany" (Schmidt, Ewald, Fischer, von Oheimb, Kriebitzsch et al. 2003). This list comprises 669 taxa for the lowlands of northern Germany and 1019 for the low mountain ranges of Germany. First, species are classified by growth form, separating species of the tree layer (B), and species of the understorey (K). The understorey (herb and shrub layer) species are further assigned to one of four subgroups: $\mathrm{K} 1$ - closely tied to forest (K1.1 - mainly in closed forest; $\mathrm{K} 1.2$ - mainly in 
forest clearings and at forest fringes); $\mathrm{K} 2$ - in forest and open vegetation (K2.1 - in forest as well as open vegetation; K2.2 - partly in forest, mainly in open vegetation). All species not listed by Schmidt et al. (2003) are called non-forest species (KO). Classification of all species in our samples was identical for both regions.

We also assigned plants to their Ellenberg indicator value for moisture (Ellenberg, Weber, Düll, Wirth, Werner et al. 1991) to determine whether plants of wet habitats, i.e. growing around wallows, were enriched in the seed bank around rubbing trees.

\section{Data analysis}

We analysed differences between trees in the mean numbers of viable seed and of plant species per soil sample with analysis of variance (ANOVA). According to the paired design with adjacent rubbing and control tress we included "site" (study forest) and "pair number" (pairs of rubbing and control trees) in the model before we fitted the factor "rubbing" (rubbing trees versus control trees in a pair). We log-transformed numbers of viable seed and species prior to analyses. Differences in counts of both single species and species groups (diaspore morphology, habitat preference, and indicator value for moisture) between all rubbing and control tree samples were tested with Fisher's exact probability (Zar 1999). One-tailed probability was used as higher counts are expected only in rubbing tree samples. Species in less than 5 samples were not tested, because it would be impossible to test for significance. Differences of plant species in number of species unique and in common for all rubbing and control samples were tested with McNemar's test (Sheskin 2000).

ANOVAs were conducted with the statistical package JMP (version 13.31, JMP Software, Cary, NC, 2000). Fisher's exact tests and McNemar's tests were carried out online (http://www.unc.edu/ preacher/fisher/fisher.htm, University of North Carolina at Chapel Hill, and http://www.fon.hum.uva.nl/Service/Statistics/McNemars test.html, Institute of Phonetic Sciences, University of Amsterdam, respectively).

\section{Results}

\section{Seed and species numbers}

A total number of 2950 seedlings appeared in the 54 soil samples, 1757 in the rubbing tree samples and 1193 in their respective controls. The number of viable seeds differed significantly both between rubbing and control trees, and the seven study areas (Table 2). The mean number of seeds germinating from soil samples near rubbing trees was higher compared with control trees (Fig. 1A). Regarding the study areas, mean seed numbers were very low in KW and very high in RW, but lowland and low mountain range sites did not differ markedly. Corresponding to the seed number near rubbing trees the vascular plant species number was significantly and on average more than twofold higher compared with control trees (Table 2, Fig. 1B). Again, study site KW exhibited the lowest and RW the highest numbers, and there were no appreciable differences between lowland and low mountain range sites.

Table 2. Summary of analyses of variance (ANOVA) of viable seeds and vascular plant species number from $500 \mathrm{~cm}^{3}$ soil samples collected near 54 study trees. Site denotes the study forests, pair number denotes the pairs of rubbing and control trees. Rubbing denotes the difference between the rubbing trees and the control trees in a pair. Prior to analysis the frequencies were log-transformed $(x+1)$. $\mathrm{DF}=$ degrees of freedom, $\mathrm{MS}=$ mean squares.

\begin{tabular}{llcccc}
\hline & Source of variation & DF & MS & F & $P$ \\
\hline Seed number & Site & 6 & 1.185 & 10.551 & $<0.001$ \\
& Pair number & 20 & 0.112 & 0.456 & 0.962 \\
& Rubbing & 1 & 2.009 & 8.156 & 0.008 \\
& Error & 26 & 0.246 & & \\
\hline Species number & Site & 6 & 0.187 & 10.993 & $<0.001$ \\
& Pair number & 20 & 0.017 & 0.452 & 0.964 \\
& Rubbing & 1 & 1.333 & 35.858 & $<0.001$ \\
& Error & 26 & 0.037 & & \\
\hline
\end{tabular}




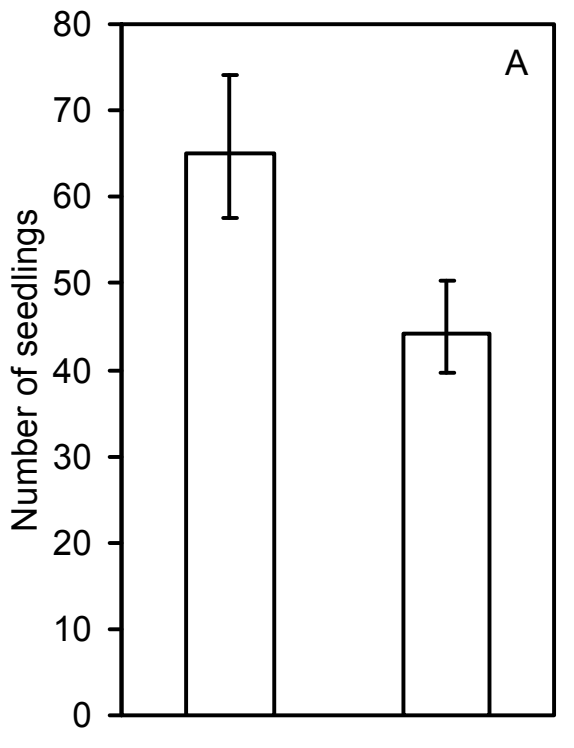

$\mathrm{R}$

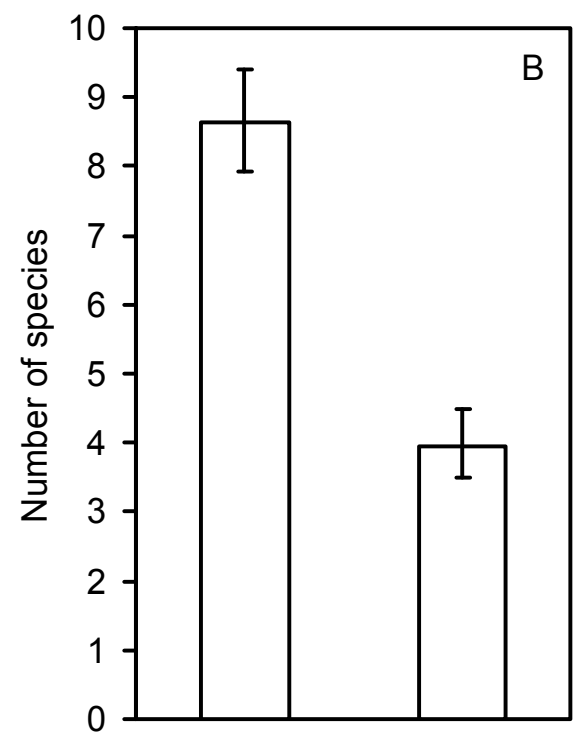

$\mathrm{R}$

C

Figure 1. Mean number of viable seeds (A) and vascular plant species (B) from $500 \mathrm{~cm}^{3}$ soil samples collected near rubbing trees $(R, n=27)$ and control trees $(C, n=27)$. Error bars represent standard errors.

\section{Plant species}

Altogether viable seeds from 61 vascular plant species were found in the 54 soil samples (Table 3). Of the 61 species, a significantly higher number of 31 exclusively appeared in soil samples collected near rubbing trees, whereas only 8 species were unique to the soil samples from undisturbed ground (McNemar's test, $p<0.001$ ). With $61.6 \%$ of all seeds and in $85.2 \%$ of the soil samples Juncus effusus was by far the most abundant species both in the rubbing and control tree samples. Ten of the 20 most frequent species ( $\geq 5$ samples) Callitriche palustris agg., Cardamine flexuosa, Chenopodium album, Deschampsia cespitosa, Juncus tenuis, Matricaria discoidea, Poa annua, Poa trivialis, Rumex sanguineus and Urtica dioica - were significantly more frequent in the soil samples near rubbing trees. In addition, Arctium sp. and Ranunculus repens seeds occurred in 4 samples only near rubbing trees, and in total the seed bank near rubbing trees contained a tenfold higher number of Stellaria media seeds. Contrasting, no species was significantly more frequent in control samples, and only very few species (above all Carex remota and Rubus idaeus) had a higher total number at the control sites.

\section{Species groups}

Hooked and bristly diaspores, i.e. those adapted to epizoochory, were significantly more frequent in the seed bank near rubbing trees than near control trees (Table 4), and also their total number was much higher (Fig. 2A). This was also true for winged diaspores which were represented largely by Callitriche palustris. Diaspores without adaptations for adhesive dispersal (i.e. with fruit pulp and without any features) showed no significant differences between rubbing and control trees. However, a significantly higher number of 17 of 29 species without any features furthering long-distance dispersal (63\%) were exclusively found near rubbing trees and only one exclusively in undisturbed ground (cf. Table 3; McNemar's test, $p$ $<0.001$ ). Altogether more seedlings of species with diaspores with a tuft of hair emerged from undisturbed samples. This depended above all on Gnaphalium uliginosum, and there was no significant difference in frequency (Table 4) and in the total number of unique species (cf. Table 3; McNemar's test). 
Table 3 (next page). Plant species germinating from the soil samples collected near rubbing trees $(R$, $n=27)$ and control trees $(C, n=27)$, and their characteristics (diaspore morphology, habitat preference according to Schmidt et al. 2003, and Ellenberg indicator value for moisture according to Ellenberg et al. 1991). The viable seed number, the number of soil samples in which the species was found and statistical significances of their association to rubbing trees are given ( $p$ value from Fisher's exact test). Abbreviations of diaspore morphology and habitat preference see method section.

\begin{tabular}{|c|c|c|c|c|c|c|c|c|c|c|c|}
\hline & \multirow{2}{*}{$\begin{array}{c}\text { Diaspore } \\
\text { mor- } \\
\text { phology }\end{array}$} & \multirow{2}{*}{$\begin{array}{c}\text { Habitat } \\
\text { pre- } \\
\text { ference }\end{array}$} & \multirow{2}{*}{$\begin{array}{l}\text { Indicator } \\
\text { value } \\
\text { moisture }\end{array}$} & \multicolumn{3}{|c|}{$\begin{array}{c}\text { Number } \\
\text { of viable seeds }\end{array}$} & \multicolumn{3}{|c|}{$\begin{array}{c}\text { Number } \\
\text { of samples }\end{array}$} & \multirow[b]{2}{*}{$p$ value } & \multirow{2}{*}{$\begin{array}{l}\text { Level of } \\
\text { signi- } \\
\text { ficance }\end{array}$} \\
\hline & & & & Total & $\mathrm{R}$ & C & Total & $\mathrm{R}$ & C & & \\
\hline Juncus effusus & unspec. & K2.1 & 7 & 1818 & 971 & 847 & 46 & 25 & 21 & 0.125 & $\mathrm{~ns}$ \\
\hline Rubus idaeus & pulp & $\mathrm{K} 1.2^{*}$ & $x$ & 71 & 28 & 43 & 29 & 12 & 17 & 0.950 & ns \\
\hline Carex remota & unspec. & $\mathrm{K} 1.1$ & 8 & 103 & 33 & 70 & 25 & 12 & 13 & 0.707 & ns \\
\hline Urtica dioica & bristly & K2.1 & 6 & 192 & 152 & 40 & 24 & 19 & 5 & $<0.001$ & $* * *$ \\
\hline Juncus tenuis & unspec. & $\mathrm{K} 2.2$ & 6 & 68 & 40 & 28 & 17 & 12 & 5 & 0.039 & * \\
\hline Deschampsia cespitosa & bristly & K2.1 & 7 & 36 & 28 & 8 & 17 & 15 & 2 & $<0.001$ & *** \\
\hline Poa annua & bristly & $\mathrm{KO}$ & 6 & 26 & 25 & 1 & 16 & 15 & 1 & $<0.001$ & $* * *$ \\
\hline Carex sylvatica & bristly & K1.1 & 5 & 24 & 9 & 15 & 12 & 7 & 5 & 0.372 & ns \\
\hline Stellaria media & unspec. & $\mathrm{K} 2.2$ & $x$ & 38 & 35 & 3 & 11 & 8 & 3 & 0.088 & ns \\
\hline Rumex sanguineus & unspec. & K1.1 & 8 & 18 & 16 & 2 & 11 & 9 & 2 & 0.020 & * \\
\hline Callitriche palustris agg. & winged & K2.1 & 10 & 199 & 199 & 0 & 9 & 9 & 0 & $<0.001$ & $* * *$ \\
\hline Cardamine flexuosa & unspec. & $\mathrm{K} 1.2$ & 8 & 9 & 9 & 0 & 7 & 7 & 0 & 0.005 & $* *$ \\
\hline Matricaria discoidea & unspec. & $\mathrm{KO}$ & 5 & 17 & 17 & 0 & 7 & 7 & 0 & 0.005 & ** \\
\hline Agrostis capillaris & unspec. & K2.1 & $x$ & 49 & 14 & 35 & 6 & 3 & 3 & 0.666 & ns \\
\hline Glechoma hederacea & unspec. & K2.1 & 6 & 7 & 4 & 3 & 6 & 3 & 3 & 0.666 & ns \\
\hline Chenopodium album & unspec. & $\mathrm{KO}$ & 4 & 18 & 18 & 0 & 5 & 5 & 0 & 0.026 & * \\
\hline Poa trivialis & bristly & K2.1 & 7 & 8 & 8 & 0 & 5 & 5 & 0 & 0.026 & * \\
\hline Digitalis purpurea & unspec. & $\mathrm{K} 1.2$ & 5 & 26 & 21 & 5 & 5 & 2 & 3 & 0.500 & ns \\
\hline Hypericum perforatum & unspec. & $\mathrm{K} 2.2$ & 4 & 8 & 6 & 2 & 5 & 3 & 2 & 0.825 & ns \\
\hline Poa pratensis & bristly & $\mathrm{K} 2.1$ & 5 & 7 & 6 & 1 & 5 & 4 & 1 & 0.175 & ns \\
\hline Betula pendula/pubescens & winged & B & $x$ & 14 & 1 & 13 & 4 & 1 & 3 & & \\
\hline Ranunculus repens & unspec. & K2.1 & 7 & 8 & 8 & 0 & 4 & 4 & 0 & & \\
\hline Arctium spec. & hooked & $?$ & $x$ & 6 & 6 & 0 & 4 & 4 & 0 & & \\
\hline Juncus bufonius & unspec. & K2.2 & 7 & 6 & 3 & 3 & 4 & 2 & 2 & & \\
\hline Gnaphalium uliginosum & hair & $\mathrm{KO}$ & 7 & 56 & 0 & 56 & 3 & 0 & 3 & & \\
\hline Conyza canadensis & hair & $\mathrm{K} 2.2$ & 4 & 4 & 2 & 2 & 3 & 2 & 1 & & \\
\hline Epilobium ciliatum & hair & $\mathrm{K} 2.2$ & 5 & 3 & 2 & 1 & 3 & 2 & 1 & & \\
\hline Luzula campestris & unspec. & K2.1 & 4 & 5 & 3 & 2 & 2 & 1 & 1 & & \\
\hline Galium aparine & hooked & K2.1 & $x$ & 3 & 3 & 0 & 2 & 2 & 0 & & \\
\hline Alnus glutinosa & winged & B & 9 & 3 & 1 & 2 & 2 & 1 & 1 & & \\
\hline Rubus fruticosus agg. & pulp & $\mathrm{K} 2.1^{*}$ & $x$ & 3 & 2 & 1 & 2 & 1 & 1 & & \\
\hline Stellaria alsine & unspec. & K2.1 & 8 & 3 & 3 & 0 & 2 & 2 & 0 & & \\
\hline Thlaspi arvense & unspec. & $\mathrm{KO}$ & 5 & 3 & 3 & 0 & 2 & 2 & 0 & & \\
\hline Scrophularia nodosa & unspec. & K2.1 & 6 & 2 & 2 & 0 & 2 & 2 & 0 & & \\
\hline Geum urbanum & hooked & $\mathrm{K} 1.2$ & 5 & 2 & 2 & 0 & 2 & 2 & 0 & & \\
\hline Festuca gigantea & bristly & K1.1 & 7 & 2 & 2 & 0 & 2 & 2 & 0 & & \\
\hline Elymus caninus & bristly & K1.1 & 6 & 2 & 2 & 0 & 2 & 2 & 0 & & \\
\hline Deschampsia flexuosa & bristly & K2.1 & $x$ & 2 & 0 & 2 & 2 & 0 & 2 & & \\
\hline Dactylis glomerata & bristly & $\mathrm{K} 2.2$ & 5 & 3 & 3 & 0 & 2 & 2 & 0 & & \\
\hline Cerastium holosteoides & unspec. & $\mathrm{K} 2.2$ & 5 & 2 & 2 & 0 & 2 & 2 & 0 & & \\
\hline Anthoxanthum odoratum & bristly & K2.1 & $x$ & 46 & 46 & 0 & 1 & 1 & 0 & & \\
\hline Capsella bursa-pastoris & unspec. & $\mathrm{KO}$ & 5 & 5 & 5 & 0 & 1 & 1 & 0 & & \\
\hline Holcus mollis & bristly & $\mathrm{K} 2.1$ & 5 & 2 & 0 & 2 & 1 & 0 & 1 & & \\
\hline Plantago major & unspec. & $\mathrm{KO}$ & 5 & 2 & 2 & 0 & 1 & 1 & 0 & & \\
\hline Taraxacum sect. Ruderalia & hair & K2.1 & 5 & 2 & 2 & 0 & 1 & 1 & 0 & & \\
\hline Veronica chamaedrys & unspec. & K2.1 & 5 & 2 & 2 & 0 & 1 & 1 & 0 & & \\
\hline Vicia tetrasperma & unspec. & $\mathrm{K} 2.2$ & 5 & 2 & 0 & 2 & 1 & 0 & 1 & & \\
\hline Viola arvensis & unspec. & $\mathrm{KO}$ & $x$ & 2 & 2 & 0 & 1 & 1 & 0 & & \\
\hline Arrhenatherum elatius & hooked & $\mathrm{K} 2.2$ & 5 & 1 & 1 & 0 & 1 & 1 & 0 & & \\
\hline Cirsium arvense & hair & $\mathrm{K} 2.2$ & $x$ & 1 & 1 & 0 & 1 & 1 & 0 & & \\
\hline Cirsium palustre & hair & K2.1 & 8 & 1 & 0 & 1 & 1 & 0 & 1 & & \\
\hline Echinochloa crus-galli & hristly & $\mathrm{KO}$ & $x$ & 1 & 1 & 0 & 1 & 1 & 0 & & \\
\hline Epilobium spec. & hair & $?$ & $x$ & 1 & 1 & 0 & 1 & 1 & 0 & & \\
\hline Festuca rubra & bristly & $\mathrm{K} 2.2$ & 6 & 1 & 0 & 1 & 1 & 0 & 1 & & \\
\hline Galium odoratum & hooked & K1.1 & 5 & 1 & 0 & 1 & 1 & 0 & 1 & & \\
\hline Persicaria hydropiper & unspec. & $\mathrm{K} 2.2$ & 8 & 1 & 1 & 0 & 1 & 1 & 0 & & \\
\hline Phacelia tanacetifolia & unspec. & $\mathrm{KO}$ & $x$ & 1 & 1 & 0 & 1 & 1 & 0 & & \\
\hline Rorippa palustris & unspec. & $\mathrm{KO}$ & 8 & 1 & 1 & 0 & 1 & 1 & 0 & & \\
\hline Sambucus nigra & pulp & $\mathrm{K} 2.1^{*}$ & 5 & 1 & 0 & 1 & 1 & 0 & 1 & & \\
\hline Veronica beccabunga & unspec. & $\mathrm{K} 2.2$ & 10 & 1 & 1 & 0 & 1 & 1 & 0 & & \\
\hline Agrostis stolonifera & unspec. & $\mathrm{K} 2.2$ & $x$ & 1 & 1 & 0 & 1 & 1 & 0 & & \\
\hline
\end{tabular}


Table 4. Diaspore morphology, habitat preference (according to Schmidt et al. 2003), and indicator values for moisture (according to Ellenberg et al. 1991) of viable seeds from soil samples near rubbing trees $(R, n=27)$ versus control trees $(C, n=27)$. The number of soil samples in which the species was found and statistical significances of their association to rubbing trees are given ( $p$ value from Fisher's exact test). For further explanation of diaspore morphology and habitat preference categories see method section.

\begin{tabular}{|c|c|c|c|c|}
\hline \multirow[b]{2}{*}{ Diaspore morphology } & \multicolumn{2}{|c|}{ Number of samples } & \multirow[b]{2}{*}{$p$ value } & \multirow{2}{*}{$\begin{array}{l}\text { Level of signifi- } \\
\text { cance }\end{array}$} \\
\hline & $\mathrm{R}$ & C & & \\
\hline Hooked & 8 & 1 & 0.012 & $*$ \\
\hline Bristly & 25 & 12 & $<0.001$ & *** \\
\hline Winged & 11 & 3 & 0.014 & * \\
\hline Hair & 6 & 5 & 0.500 & ns \\
\hline Pulp & 13 & 18 & 0.951 & ns \\
\hline Unspecific & 26 & 23 & 0.175 & ns \\
\hline \multicolumn{5}{|l|}{ Habitat preference } \\
\hline K1.1 - closely tied to forest & 21 & 17 & 0.186 & ns \\
\hline $\mathrm{K} 1.2$ - forest clearings and fringes & 17 & 18 & 0.715 & ns \\
\hline K2.1 - forest and open vegetation & 27 & 22 & 0.026 & * \\
\hline K2.2 - mainly in open vegetation & 21 & 11 & 0.006 & ** \\
\hline KO - non-forest species & 21 & 4 & $<0.001$ & *** \\
\hline Others - trees + undetermined & 7 & 3 & 0.147 & ns \\
\hline \multicolumn{5}{|l|}{ Ellenberg indicator value } \\
\hline F4 & 8 & 4 & 0.163 & ns \\
\hline F5 & 19 & 10 & 0.014 & * \\
\hline F6 & 23 & 11 & $<0.001$ & $\star \star * *$ \\
\hline $\mathrm{F} 7$ & 25 & 21 & 0.125 & $\mathrm{~ns}$ \\
\hline F8 & 23 & 16 & 0.033 & * \\
\hline $\mathrm{F} 9+\mathrm{F} 10$ & 11 & 1 & 0.001 & ** \\
\hline
\end{tabular}

Diaspore morphology

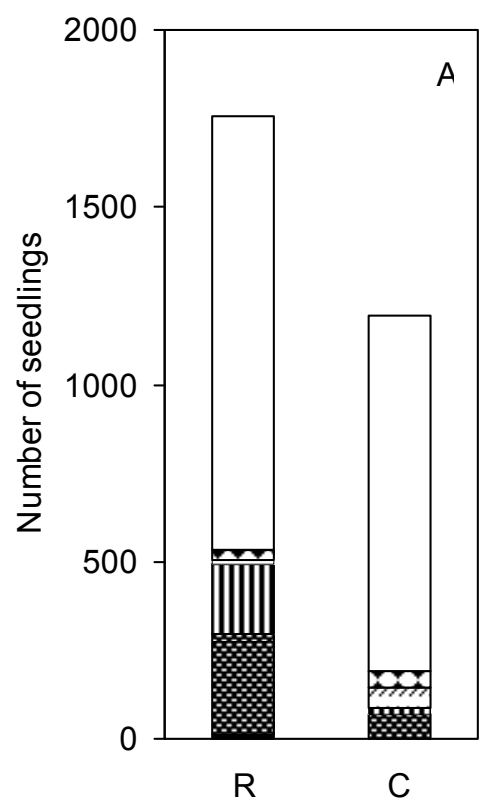

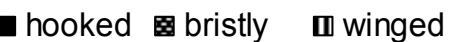
$\square$ hair a pulp $\square$ unspec.

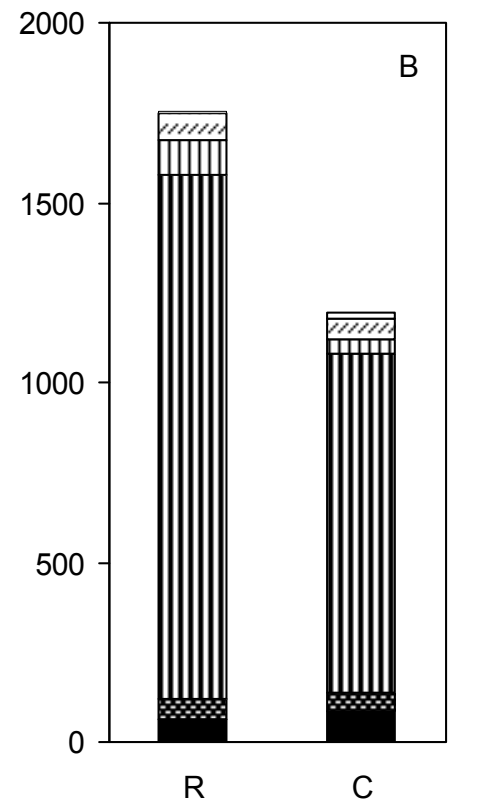

K1.1 $\mathrm{DK} 2.2$
Habitat preference

K1.2
II K2.1 $\square \mathrm{KO}$ $\square$ Others

Figure 2. Spectra of all viable seeds from the soil samples near rubbing trees $(R, n=27)$ and control trees $(C, n=27)$. A diaspore morphology; $B$ Habitat preference; $C$ Ellenberg indicator value for moisture. Abbreviations for A und B see method section. Note: dominance of categories "unspec." in A, "K2.1" in B and "F7" in C predominantly depends on Juncus effusus. 
Comparing the habitat preference of seeds reveals that plant species closely tied to forest, forest clearings and forest fringes (species groups K1.1. and K1.2, above all Carex remota, C. sylvatica, Rumex sanguineus and Rubus idaeus) showed no significant differences both in frequency (Table 4) and total number (Fig. 2B). However, species which occur both in forest and open vegetation (species groups K2.1 and K2.2, above all Deschampsia cespitosa, Juncus spp. and Urtica dioica) which accounted for the main part of the seed banks, were significantly more frequent near rubbing trees compared with controls. This was also true for species which exclusively occur in open vegetation like Chenopodium album, Matricaria discoidea and Poa annua.

Among the vascular plants found in soil samples from rubbing tree sites, those with medium (F5, F6) and high (F8, F9, F10) Ellenberg indicator values for moisture were significantly more frequent compared to control sites (Table 4). Species indicating moderately dry (F4) and moderately moist (F7) habitats and those with a broad amplitude (FX) had similar frequencies in both types of sites. Regarding the total number of diaspores, wetness indicators (F9, F10) like Callitriche palustris were largely restricted to rubbing trees (Fig. 2C).

\section{Discussion}

\section{Seed and species numbers in the seed bank}

As predicted, both the number of viable seeds and the total number of vascular plant species was higher ( $67.9 \%$ and $76.7 \%$, respectively) in the soil samples collected near rubbing trees than the controls, and species richness was more than twofold higher in single samples. The large number of seeds and plant species, of which several were exclusive, found in soil samples collected at rubbing trees as compared with the controls is difficult to explain unless the majority of these diaspores and species were dispersed by wild boar. These results generalize previous findings. Mrotzek et al. (1999) and Welander \& Weibull (2000) reported an about threefold higher number of viable seeds and vascular plant species in soil samples from rubbing trees. The lower differences in our study mainly depend on the dominance of Juncus effusus in the seed bank, which was not significantly affected by rubbing activities of wild boar; excluding Juncus effusus from the analysis would lead to numerical proportions very similar the previous studies.

On average 20 viable seeds per sample $\left(100 \mathrm{~cm}^{2}\right)$ may have resulted from dispersal by wild boar in our study, leading to an estimate of at least 1.000 seeds which were deposited near one rubbing tree on the basis of a deposition area of $0.5 \mathrm{~m}^{2}$. Comparing this approximation with the mean number of diaspores transported epizoochorically on one wild boar (Mrotzek et al. 1999, Heinken \& Raudnitschka 2002, Schmidt et al. 2004) we conclude that several complete diaspore loads were deposited near each tree, indicating that rubbing trees are used repeatedly. As rubbing trees are abundant in many forested areas (Bavoux 1981, Welander \& Weibull 2000 and own observations), large amounts of seed are dispersed to rubbing trees on the landscape level.

\section{Plant species composition of the seed bank}

Plant species closely tied to forest which are well represented in the vegetation of all study sites were poorly represented in the seed bank (Fig. 2B). This is in accordance with most studies on viable seeds in the soil of European temperate forest ecosystems (Augusto, Dupouey, Picard \& Ranger 2001, Bossuyt \& Hermy 2001). Seed banks largely consist of light demanding species of disturbed environments which have disappeared from the ground flora, while the proportions of herb species of closed forest as well as tree and shrub species are generally low (Augusto et al. 2001, Bossuyt \& Hermy 2001, Bossuyt, Heyn \& Hermy 2002). This is, because typical forest species produce short-living diaspores in relatively low numbers, leaving few opportunities for incorporation in persistent seed banks.

At the species level our seed banks coincide with those of other European temperate forests to a large extent. In many cases Juncus effusus which produces very small seeds and especially appears after clear-cuts is the dominant species (e.g. Bossuyt et al. 2002). Other typical plants of forest clearings like Digitalis purpurea and Rubus idaeus are also reported to be common in woodland seed banks (e.g. Augusto et al. 2001, Mayer, Abs \& Fischer 2004). This is also true for some species closely tied to forests like Carex sylvatica 
and C. remota (e.g. Augusto et al. 2001, Bossuyt et al. 2002). Altogether, nearly all species which were abundant both near rubbing and control trees also were abundant in other seed bank studies of temperate forests.

However, seed density, species numbers (see Table 2), and species composition varied between the study areas to a large extent. First, this is dependent on the different forest types investigated. For example, there are large differences in the seed bank composition between deciduous and coniferous forests (Augusto et al. 2001, Bossuyt \& Hermy 2001). Secondly, seed banks reflect the history of forests. Soil disturbances due to forest management or windthrow, and the accompanying increasing light intensity will allow the regeneration and subsequent dissemination of early successional species from buried seeds (Bossuyt \& Hermy 2001, Olano, Caballero, Leskurain, Loidi \& Escudero 2002). If forests then remain undisturbed for a longer period, most buried seeds of those species lose their viability and the seed bank gradually depletes with increasing stage age (Augusto et al. 2001).

Using pairwise comparisons between adjacent rubbing and control trees the effect of seed dispersal by wild boar persists beyond the extensive differences in seed bank composition of the study areas and forest communities, and the significant small-scale spatial structure of forest soil seed banks (Olano et al. 2002). Most of the plant species which were significantly more frequent near rubbing trees were also abundant in the coats of shot wild boar (Mrotzek et al. 1999, Heinken \& Raudnitschka 2002, Schmidt et al. 2004). For example, Urtica dioica was one of the dominant species, Deschampsia cespitosa and Poa spp. were frequent in all studies, and Rumex sanguineus was common in two of the investigated areas.

\section{Dispersal of different plant species groups}

For the first time our results clearly indicate the epizoic dispersal of hooked and bristly diaspores, of plant species with habitat preference in both forest and open vegetation and non-forest species, and of wetness indicators to rubbing trees by wild boar (Table 4, Fig. 2). Moreover, there is evidence for the dispersal of unspecialised diaspores (Table 3, cf. Welander \& Weibull 2000). In contrast, diaspores adapted to wind dispersal and endozoochory, and plant species which are largely restricted to forest habitats, may play a minor role in epizoic dispersal by wild boar. These findings are consistent with our hypotheses and with diaspore loads in the coats and hooves of shot wild boar in central Europe (Mrotzek et al. 1999, Heinken et al. 2002, Heinken \& Raudnitschka 2002, Schmidt et al. 2004). For example, bristly diaspores made up the majority, while the proportion of hooked ones was less than $10 \%$ among wild boars shot in NE Germany (Heinken \& Raudnitschka 2002). Furthermore, a considerable amount of diaspores lacking evident dispersal attributes was detected in that study.

In the tests of Couvreur et al. (2004) adhesivity of seeds in wild boar fur was highly negatively correlated with seed size, whereas - in contrast to all other tested furs - no correlation had been found with appendage length or density. Under the given experimental conditions (seeds were dropped perpendicularly on the fur) the thick-haired, but not very dense fur of wild boar seemed to favour the retention of small, unspecialised seeds more than the retention of seed with appendages. The inconsistence between field studies and the experiments of Couvreur et al. (2004) elucidates that full understanding of the process of epizoochory requires an integration of knowledge about all influencing factors, e.g. plant traits such as the height of seed exposure and the duration of disseminating period (Fischer et al. 1996), as well as animal movement and behaviour like wallowing and grooming.

Non-forest species, and species with habitat preference in forest and open vegetation dominated among plants transported externally, which was also true for shot wild boar both in NW and NE Germany (Heinken \& Raudnitschka 2002, Schmidt et al. 2004). Most of these diaspores must have been picked up outside the forest stands to which they were dispersed also in our study. This is, because arable land which is an important source of food (Hahn 2002), grasslands, ruderal vegetation and waysides are important habitats for wild boar. Moreover, open vegetation species produce more diaspores than plant species restricted to forests, and their diaspore morphology is generally more suited for epizoic dispersal (see Heinken et al. 2002, Heinken \& Raudnitschka 2002). A new aspect of our results is the preferential dispersal of several wetness indicators like Callitriche palustris agg., Cardamine flexuosa, Persicaria hydropiper or Veronica beccabunga, which grow especially in and near the wallows. 
Using seed banks near rubbing trees is an indirect way to evaluate seed dispersal by wild boar which implies some methodical problems. First, it is difficult to verify dispersal of single plant species. Secondly, as samples were taken during the winter half year, some early fruiting woodland species with transient seed banks may already have disappeared from soil samples. A final source of error is that there is a probability that some of the control trees had been used as rubbing trees occasionally or in earlier years, but potential contamination of control samples would strengthen our results. However, to study the diaspore dispersal capacity of shot animals (e.g. Heinken \& Raudnitschka 2002, Schmidt et al. 2004) also imposes problems. First, diaspore loads of killed animals provide only a snap-shot which reflect the diaspore offer at the respective point of time, while seed bank investigations following the dissemination period should integrate dispersal during the whole vegetation period. Secondly, contamination with diaspores occurs inevitably when the animals fall. Given the importance to hunters of being at the right place to make a kill, there is also a potential bias of where the animals were shot and in what vegetation they fell.

\section{Dispersal paths and distances}

Diaspores may adhere to the coats and hooves of wild boar when animals move between feeding and resting sites, between wallows and rubbing trees and when rooting or building nests. Being encapsulated in the mud, they may also attach when a wild boar wallows. Although many diaspores fall off almost immediately, some probably stay on the animal for longer periods, at least up to several days (Fischer et al. 1996, Bonn \& Poschlod 1998). By telemetric observations Sodeikat \& Pohlmeyer (2003) determined home ranges of 166 to 2.244 ha for wild boar in NW Germany, and Truve \& Lemel (2003) found a mean activity range of 104 ha in Sweden. The mean distances animals moved per activity bout were 3.7 $\mathrm{km}$ and $7.2 \mathrm{~km}$, respectively. Thus diaspores are likely to be dispersed over one up to several kilometres. Migratory movements of animals may lead to exceptional long-distance dispersal events. Wild boar groups tracked by Sodeikat \& Pohlmeyer (2003) left their central area after hunt and moved on almost $6 \mathrm{~km}$ away, and Truve \& Lemel (2003) determined dispersal of males $16.6 \mathrm{~km}$ from their natal sites.

Like adherence, detachment of diaspores may also happen on any movement. Normally diaspores will fall off the animal by chance, those which are encapsulated in the mud especially when the mud dries, cracks and eventually falls off. Many diaspores, both those attached during movements and in wallows, will be deposited at rubbing trees near the wallows and enter the seed bank immediately or after being washed from the stem basis by rain. $\mathrm{Fi}$ nally, a considerable amount of diaspores will be transported to other wallows and detach when the mud in the coats is rewetted and stirred with the mud in the wallow. Hence, diaspores from different habitats - forest, wallows and remote open landscape- are deposited next to rubbing trees, and these diaspores may be at least somewhat representative for overall dispersal.

\section{Conclusions}

Our seed bank study confirms previous assumptions that wild boar transport considerable amounts of diaspores of almost all morphological types except for those with fruit pulps and very large ones without dispersal-relevant appendages, and that plant species restricted to forest habitats are underrepresented in central European dispersal spectra due to low seed production and lacking morphological adaptations for epizoochorous transportation of diaspores.

Beyond this, our results imply a directed dispersal of plant species inhabiting wallows by wild boar: Normally depressions with slack water which can be used as wallows are specific habitats embedded in a matrix of less moist habitats, occupied by species requiring unusual edaphic conditions. As wild boar as dispersal agents will use diverse wallows they take many seeds to non-random places which are best possible for establishment. Thus, there is evidence for the "directed dispersal hypothesis" established by Howe \& Smallwood (1982) describing the advantages of seed dispersal.

We also demonstrated that in the agricultural landscape of central Europe wild boar epizoochorically transports large amounts of seed of plant species growing in the open landscape into forest stands, and a rough quantification of seed deposition is feasible. However, species with habitat preference in open vegetation and non-forest species are adapted to 
disturbance and high light intensity conditions and thus do not germinate under forest cover, but enter the soil seed bank (see Heinken et al. 2002, Heinken \& Raudnitschka 2002). Buried seeds of these species might especially emerge after windthrow or forest management like clear-cuts (e.g., Bossuyt \& Hermy 2001) and then contribute to an increased phytodiversity. As rooting (and wallowing) leads to extensive soil disturbances (Welander 2000) wild boar may promote establishment of dispersed seeds at the same time. Distribution of rubbing trees in forests is clustered (Welander \& Weibull 2000, own observations). Epizoic transport of diaspores by wild boar will therefore lead to a clustered deposition of dispersed seeds which may have consequences for the forest vegetation difficult to evaluate at present time.

As our results are consistent within different central European study areas, show a strong coincidence with data obtained from shot animals and add new aspects to the understanding of plant dispersal by wild boar, we state that beyond some methodical problems soil seed bank investigations near rubbing trees are useful means to evaluate epizoic dispersal by wild boar.

\section{Acknowledgements}

We thank Markus Fischer (Potsdam) for constructive comments on the manuscript and Mark van Kleunen (Potsdam) for statistical advice.

\section{References}

Augusto, L., Dupouey, J.L., Picard, J.F., \& Ranger, J. (2001). Potential contribution of the seed bank in coniferous plantations to the restoration of native deciduous forest vegetation. Acta Oecologica, 22, 87-98.

Bavoux, C. (1981). Contribution à l'étude des arbres frottés par les sangliers (Sus scrofa L.). Annales de la Société des Sciences Naturelles de la Chanrente-Maritime, 6, 859-870.

Bonn, S., \& Poschlod, P. (1998). Ausbreitungsbiologie der Pflanzen Mitteleuropas. Wiesbaden: Quelle \& Meyer.

Bossuyt, B., \& Hermy, M. (2001). Influence of land use history on seed banks in European temperate forest ecosystems: a review. Ecography, 24, 225-238.

Bossuyt, B., Heyn, M., \& Hermy, M. (2002). Seed bank and vegetation composition of forest stands of varying age in central Belgium: consequences for regeneration of ancient forest vegetation. Plant Ecology, 162, 33-48.

Brunet, J., \& von Oheimb, G. (1998). Migration of vascular plants to secondary woodlands in southern Sweden. Journal of Ecology, 86, 429-438.

Cain, M.L., Milligan, B.G., \& Strand, A.E. (2000). Long-distance seed dispersal in plant populations. American Journal of Botany, 87, 1217-1227.

Couvreur, M., Vandenberghe, B., Verheyen, K., \& Hermy, M (2004). An experimental assessment of seed adhesivity on animal furs. Seed Science Research, 14, 147-159.

Dardaillon, M. (1986). Seasonal variation in habitat selection and spatial distribution of wild boar (Sus scrofa) in the Camargue, southern France. Behavioural Processes, 13, 251-268.

Diekmann, M., Brunet, J., Rühling, A., \& Falkengren-Grerup, U. (1999). Effects of nitrogen deposition: results of a temporal-spatial analysis of deciduous forests in South Sweden. Plant Biology, 1, 471-481.

Ellenberg, H., Weber, H.E., Düll, R., Wirth, V., Werner, W., \& Paulißen D (1991). Zeigerwerte von Pflanzen in Mitteleuropa. Scripta Geobotanica, 18, 1-248.

Fischer, S.F., Poschlod, P., \& Beinlich, B. (1995). Experimental studies on the dispersal of plants and animals on sheep in calcareous grasslands. Journal of Applied Ecology, 33, 1206-1222.

Gill, R.M.A., \& Beardall, V. (2001). The impact of deer on woodlands: the effects of browsing and seed dispersal on vegetation structure and composition. Forestry, 74, 209-218.

Graae, B.J. (2002). The role of epizoochorous seed dispersal of forest plant species in a fragmented landscape. Seed Science Research, 12, 113-120.

Hahn, N. (2002). Raumnutzung und Ernährung von Schwarzwild. LWF aktuell, 35, 32-34.

Heinken, T. (2004). Migration of an annual myrmecochore: a four-year-experiment with Melampyrum pratense L. Plant Ecology, 170, 55-72.

Heinken, T., \& Raudnitschka, D. (2002). Do wild ungulates contribute to the dispersal of vascular plants in central European forests by epizoochory? A case study in NE Germany. Forstwissenschaftliches Centralblatt, 121, 179-194. 
Heinken, T., Hanspach, H., Raudnitschka, D., \& Schaumann, F. (2002). Dispersal of vascular plants by four species of wild mammals in a deciduous forest in NE Germany. Phytocoenologia, 32, 627-643.

Higgins, S.I., Nathan, R., \& Cain, M.L. (2003). Are long-distance dispersal events in plants usually caused by non-standard means of dispersal? Ecology, 84, 1945-1956.

Howe, H.F., \& Smallwood, J. (1982). Ecology of seed dispersal. Annual Review of Ecology, Evolution, and Systematics, 13, 201-228.

Kiviniemi, K. (1996). A study of adhesive seed dispersal of three species under natural conditions. Acta Botanica Neerlandica, 45, 73-83.

Klein, M. (1997). Naturschutz und Erstaufforstung. Schriftenreihe für Landschaftspflege und Naturschutz, 49, 1-171.

Kollmann, J. (2000). Dispersal of fleshy-fruited species: a matter of spatial scale? Perspectives in Plant Ecology, Evolution and Systematics, 3, 29-51.

Lemel, J., Truve, J., \& Soderberg, B. (2003). Variation in ranging and activity behaviour if wild boar Sus scrofa in Sweden. Wildlife Biology, 9, Suppl. 1, 29-36.

Levy, P.E., \& Milne, R. (2004). Estimation of deforestation rates in Great Britain. Forestry, 7, 9-16.

Mayer, P., Abs, C., \& Fischer, A. (2004). Colonisation by vascular plants after soil disturbance in the Bavarian Forest - key factors and relevance for forest dynamics. Forest Ecology and Management, 188, 279-289.

Mrotzek, R., Halder, M., \& Schmidt, W. (1999). Die Bedeutung von Wildschweinen für die Diasporenausbreitung von Phanerogamen. Verhandlungen der Gesellschaft für Ökologie, 29, 437-443.

Oheimb, G. von, Schmidt, M., Kriebitzsch, W.U., \& Ellenberg, H. (in press). Dispersal of vascular plants by game in Northern Germany. Part II: Red deer (Cervus elaphus). European Journal of Forest Research.

Olano, J.M., Caballero, I., Laskurain, N.A., Loidi, J., \& Escudero, A (2002). Seed bank spatial pattern in a temperate secondary forest. Journal of Vegetation Science, 13, 775-784.

Ouborg, N.J., Piquot, Y., \& van Groenendael, J.M. (1999). Population genetics, molecular markers and the study of dispersal in plants. Journal of Ecology, 87, 551-568.

Peterken, G. F., \& Game, M. (1984). Historical factors affecting the number and distribution of vascular plant species in the woodlands of central Lincolnshire. Journal of Ecology, 72, 155-182.

Poschlod, P., Bakker, J.P., Bonn, S., \&; Fischer, S. (1996). Dispersal of plants in fragmented landscapes. In: J. Settele, C.R. Margules, P. Poschlod \& K. Henle. (Eds.), Species survival in fragmented landscapes (pp. 123-127). Dordrecht:Kluwer. .

Schmidt, M., Ewald, J., Fischer, A., von Oheimb, G., Kriebitzsch, W.U., Ellenberg, H., \& Schmidt, W. (2003). Liste der in Deutschland typischen Waldgefäßpflanzen. Mitteilungen der Bundesforschungsanstalt für Forst- und Holzwirtschaft 212: 1-34.

Schmidt, M., Sommer, K., Kriebitzsch, W.U., Ellenberg, H., \& von Oheimb, G. (2004). Dispersal of vascular plants by game in Northern Germany. Part I: Roe deer (Capreolus capreolus) and Wild Boar (Sus scrofa). European Journal of Forest Research, 123, 167-176.

Sodeikat, G., \& Pohlmeyer, K. (2003). Escape movements of family groups of wild boar Sus scrofa influenced by drive hunts in Lower Saxony, Germany. Wildlife Biology, 9, Suppl. 1, 43-49.

Truve, J., \& Lemel, J. (2003). Timing and distance of natal dispersal for wild boar Sus scrofa in Sweden. Wildlife Biology, 9, Suppl. 1, 51-57.

Welander, J. (2000). Spatial and temporal dynamics of wild boar (Sus scrofa) rooting in a mosaic landscape. Journal of Zoology, 252, 263-271.

Welander, J., \& Weibull, H. (2000). Wild boar (Sus scrofa) as a dispersal vector of vascular plants and bryophytes. In: J. Welander, Spatial and temporal dynamics of a disturbance regime: wild boar (Sus scrofa L.) rooting and its effects on plant species diversity. PhD Thesis, Swedish University of Agricultural Sciences, Uppsala, Sweden.

Wisskirchen, R., \& Haeupler, H. (1998). Standardliste der Farn- und Blütenpflanzen Deutschlands. Stuttgart: Ulmer Verlag.

Sheskin, D. J. (2000). Handbook of parametric and nonparametric statistical procedures ( $2^{\text {nd }}$ ed.). Boca Raton: Chapman \& Hall.

Wulf, M. (2003). Forest policy in the EU and its influence on the plant diversity of woodlands. Journal of Environmental Management, 67, 15-25.

Wulf, M. (2004). Plant species richness of afforestations with different former use and habitat continuity. Forest Ecology and Management, 195, 191-204.

Zar, J.H. (1999). Biostatistical Analysis. 4th ed. London: Prentice-Hall.

Zerbe, S. (2002). Restoration of natural broad-leaved woodland in Central Europe on sites with coniferous forest plantations. Forest Ecology and Management, 167, 27-42. 